\title{
The Children's Republic of Science in the Antebellum Literature of Samuel Griswold Goodrich and Jacob Abbott
}

\author{
By Katherine Pandora*
}

\begin{abstract}
The antebellum years in the United States were marked by vigorous debates about national identity in which issues of hierarchy, authority, and democratic values came under intense scrutiny. During this period, a prime objective of indigenous authors writing for American children was educating the young so they would be ready to assume their republican responsibilities. The question of how depictions and discussions about nature and science were deployed toward this end is explored by examining key texts about nature and science from the era's two most prolific and popular children's authors-Samuel Griswold Goodrich (1793-1860) and Jacob Abbott (1803-79) — and highlighting assumptions within these works about what the proper relationship should be between the search for scientific knowledge and the larger polity.
\end{abstract}

\section{INTRODUCTION}

What did it mean to be a scientific American in the nineteenth century? One set of answers to this question can be found by examining the organizing of scientific societies, following the various paths that individuals took to earning higher degrees, and analyzing the practices and theories that contributed to the realization of disciplinary identities - foundational events that made possible the first volume of James McKeen Cattell's American Men of Science in 1906. In large measure, when historians of American science have studied the nineteenth century, it is this set of answers that they have pursued most diligently. ${ }^{1}$ And yet studies of the making of American

\footnotetext{
*Department of the History of Science, University of Oklahoma, 601 Elm Avenue, Physical Sciences Bldg. 619, Norman, OK 73019; kpandora@ ou.edu.

As a fellow at the Charles Warren Center for Studies in American History at Harvard University, I benefited greatly from the insights of Charles Rosenberg, Joyce Chaplin, and Laurel Thatcher Ulrich, the directors of our year-long investigation into the topic "Exceptional by Nature? American Science and Medicine, 1600-1900," as well as those of the other fellows: Jorge Cañizares-Esguerra, Cornelia Dayton, Mordechi Feingold, Ann Johnson, Marina Moskowitz, Susan Scott Parrish, and Alice N. Walters. I also appreciate the thoughtful commentary from the referee process for this paper and from the workshop that preceded this volume, which included the other authors as participants, as well as Michael Adas, John Krige, and Laura Dassow Walls.

${ }^{1}$ The interest of a previous generation in professionalization led to a vigorous research program that encompassed numerous scholarly articles, editions of collected essays, bibliographic resources, and biographical treatments. Examples of key texts include: A. Hunter Dupree, Science in the Federal Government (Cambridge, Mass., 1957); George Daniels, American Science in the Age of Jackson
}

๑ 2009 by The History of Science Society. All rights reserved. 0369-7827/09/2009-0005\$10.00 
scientists alone cannot answer this question. As the citizens of the former colonies turned new republic engaged in the dynamics of nation building over the course of the nineteenth century, their experiences with and interpretations of the natural world they inhabited - in its physical, faunal, floral, and human forms-were crucial resources they used in debates about what was at stake in the American experiment in self-government as sanctioned by the "Laws of Nature and of Nature's God."2 Indeed, the turbulent era between Andrew Jackson and Abraham Lincoln was decisive in establishing the contours of argument about creating an American republic: it is in this formative period that the first generational cohorts who inherited the Revolution came of age and engaged in intense explorations about the meaning of national identity, with understandings of American "nature(s)" being central to key aspects of this ferment. ${ }^{3}$

Within vernacular discourse about the natural world, books for American children written by native authors have been unduly neglected by scholars as a means for exploring the intellectual, social, and political ramifications of ideas about nature and science in American culture during this period. Indeed, a push for a specifically American literature for youngsters that began in the1820s had burgeoned by midcentury, stimulated by changing views of childhood itself and fostered by a worry that imported literature presented "a wrong direction to the minds of the young, modeled as they are on a condition of life, and on prevailing sentiments, civil, moral and social .. . varying from those which American children should early be taught to cherish." As Anne Scott MacLeod remarks, nineteenth-century Americans "wanted American

(New York, 1968); Howard S. Miller, Dollars for Research: Science and Its Patrons in NineteenthCentury America (Seattle, Wash., 1970); Sally Gregory Kohlstedt, The Formation of the American Scientific Community: The American Association for the Advancement of Science, 1848-1860 (Carbondale, Ill., 1976); and Robert Bruce, The Launching of Modern American Science, 1846-1876 (New York, 1987). Although this work did discuss popular science to some extent in contextualizing the world from which professionalism diverged, this was not a key focus. Subsequent, more sustained engagement regarding popular science in this time by historians of science can be found in: Elizabeth Keeney, The Botanizers: Amateur Scientists in Nineteenth-Century America (Chapel Hill, N.C., 1993); Daniel Goldstein, "'Yours for Science': The Smithsonian Institution's Correspondents and the Shape of Scientific Community in Nineteenth-Century America," Isis 85 (1994): 573-99; and Sally Gregory Kohlstedt, "Parlors, Primers, and Public Schooling: Education for Science in NineteenthCentury America," Isis 81 (1990): 425-45.

2 The most interesting insights into the cultural meanings of natural knowledge in this period can be found in the interdisciplinary efforts of art historians, literary scholars, and those working in American Studies. As examples, see: Barbara Novak, Nature and Culture: American Landscape and Painting, 1825-1875 (New York, 1981); Laura Dassow Walls, Seeing New Worlds: Henry David Thoreau and Nineteenth-Century Natural Science (Madison, Wis., 1995); Margaret Welch, The Book of Nature: Natural History in the United States, 1825-1875 (Boston, 1998); and Christoph Irmscher, The Poetics of Natural History, from John Bartram to William James (New Brunswick, N.J., 1999).

${ }^{3}$ For issues such as nationalism, identity, and cultural debates in this time period, relevant texts are: Gordon Wood, "The Significance of the Early Republic," Journal of the Early Republic 8 (1988): 1-20; Charles Sellers, The Market Revolution: Jacksonian America, 1815-1846 (New York, 1994); Anne C. Rose, Voices of the Marketplace: American Thought and Culture, 1830-1860 (New York, 1995); David Waldstreicher, In the Midst of Perpetual Fetes: The Making of American Nationalism, 1776-1820 (Chapel Hill, N.C., 1997); Lawrence Levine, Highbrow/Lowbrow: The Emergence of Cultural Hierarchy in America (Cambridge, Mass., 1998); Joseph A. Conforti, Imagining New England: Explorations of Regional Identity from the Pilgrims to the Mid-Twentieth Century (Chapel Hill, N.C., 2000); Joyce Appleby, Inheriting the Revolution: The First Generation of Americans (Cambridge, Mass., 2001); and Jill Lepore, A Is for American: Letters and Other Characters in the Newly United States (New York, 2002). 
books for their children of destiny."4 Nearly two decades ago, Sally Gregory Kohlstedt urged historians of science to "dig deeper into the national record" to better explain the "pervasive public curiosity about scientific subjects" in the nineteenthcentury United States; she memorably argued for the relevance of "parlors, primers, and public schooling" in underwriting a variety of private and public responses to "cultural initiatives in the history of science in America, past and present." She suggested that "books for children particularly underscore the enthusiasm for science."5

In taking up scientific themes in instructing these children of destiny, what visions of the scientific enterprise did American authors convey? What aspects of natural lore and natural law did they believe were best suited to forming the growing mind and soul, and what were the ramifications of these assumptions? How did they place the middle-class American child within the natural and moral economy of the search for natural knowledge, and for what purposes? The generational cohort of Americans who worked at influencing their fellow citizens in the middle decades of the nineteenth century included such prominent individuals as Samuel Griswold Goodrich (1793-1860) and Jacob Abbott (1803-79), who developed and presented a vision of scientific Americanism to the young that emphasized natural knowledge as common property, acquired through mutual and united effort. ${ }^{6}$ Adopting formats that favored

${ }^{4}$ William Cardell, The Story of Jack Halyard, 3rd ed. (Philadelphia, 1825), quoted in Anne Scott MacLeod, A Moral Tale: Children's Fiction and American Culture, 1820-1860 (Hamden, Conn., 1975), 20. On American society and childhood and/or juvenile literature in this period, see Gillian Avery, Behold the Child: American Children and Their Books, 1621-1922 (Baltimore, 1994); R. Gordon Kelley, Mother Was a Lady: Self and Society in Selected American Children's Periodicals, 18651890 (Westport, Conn., 1974); Monica Kiefer, American Children through Their Books, 1790-1835 (Philadelphia, 1948); Gail Schmunck Murray, American Children's Literature and the Construction of Childhood (New York, 1998); Jacqueline Reinier, From Virtue to Character: American Childhood, 1775-1850 (New York, 1996); and Bernard Wishy, The Child and the Republic: The Dawn of Modern American Child Nurture (Philadelphia, 1968). On information circulation and the emergence of a reading public, essential starting points are: Richard D. Brown, Knowledge Is Power: The Diffusion of Information in Early America, 1700-1865 (New York, 1989); and Ronald J. Zboray, A Fictive People: Antebellum Economic Development and the American Reading Public (New York, 1993).

${ }^{5}$ Kohlstedt, "Parlors, Primers, and Public Schooling" (cit. n. 1), 425, 436. In 1985, James Secord noted that "inquiry into the special historical problems of presenting science to a juvenile audience has barely begun"; there is much spadework yet to be done, particularly for the American context. Part of the issue is the assumption that "children's books sit securely on the bottom rung of historical significance, for here truth is in the most dilute form possible." See James A. Secord, "Newton in the Nursery: Tom Telescope and the Philosophy of Tops and Balls, 1761-1838," History of Science 23 (1985): 127-51, 127, 128. Among research that has begun to develop in this area is Aileen Fyfe, "Young Readers and the Sciences," in Books and the Sciences in History, ed. Marina Frasca-Spada and Nick Jardine (Cambridge, UK, 2000), 276-90; Barbara T. Gates, "Revisioning Darwin with Sympathy: Arabella Buckley," Pamela Henson, “Through Books to Nature': Anna Botsford Comstock and the Nature Study Movement," and Greg Myers, "Fictionality, Demonstration, and a Forum for Popular Science: Jane Marcet's Conversations on Chemistry," in Natural Eloquence: Women Reinscribe Science, ed. Barbara T. Gates and Ann B. Shteir (Madison, Wis., 1997); Barbara T. Gates, Kindred Nature: Victorian and Edwardian Women Embrace the Living World (Chicago, 1998); Keeney, Botanizers (cit. n. 1); Greg Myers, "Science for Women and Children: The Dialogue of Popular Science in the Nineteenth Century," in Nature Transfigured: Science and Literature, 1700-1800, ed. John Christie and Sally Shuttleworth (Manchester, UK, 1989), 171-200; and Harriet Ritvo, "Learning from Animals: Natural History for Children in the Eighteenth and Nineteenth Centuries," Children's Literature 13 (1985): 72-93.

${ }^{6}$ Although Goodrich and Abbott are well known as popular juvenile authors in the history of children's literature, sustained analysis of their work and lives has been sporadic and extended secondary material surprisingly scarce. Concise entries in the American National Biography for each are useful starting points; fuller descriptions are contained in the Dictionary of Literary Biography. Other discussions of their places within the history of children's literature are contained in Avery, Behold 
a welcoming tone and that featured unintimidating entry points into learning about a shared world of questions and answers, they helped to place the youngest citizens in the republic of science on a stable footing that, ideally, would allow the experiences of all to count in working out an understanding of American nature. ${ }^{7}$ It was a plain style that eschewed constant reference to learned authorities, placed little emphasis on expensive instruments or complicated terminology, and promoted a belief in a democracy of learners, rather than an aristocracy of intellect.

The relaxed, inclusive, and optimistic approach of these authors to scientific education is one that was not premised on inculcating deference to learned authorities but was instead informed by a republican ethos that presumed the intellectual capacity of self-motivated learners to work independently toward goals of their own choosing. This cultural latitudinarianism on scientific topics is one that would find increasing disfavor among professionalizing scientific elites in the latter half of the nineteenth century. They would argue that popular approaches to science needed to be brought into closer alignment with the values and priorities that they identified as primary, particularly a more restrictive vision of intellectual authority compatible with the hierarchical norms of elite science current in Britain and Europe. In this sense, reading these children's authors can provide insight into views about the place of scientific knowledge within the larger American polity. Scholars have typically seen these texts as simply efforts to impart child-size bits of scientific information to the young for their edification, but they were more than this. They were also vehicles for forging readers' sensibilities toward the search for natural knowledge as properly personal, communal, and consequential in a mutual constitution of self and nation: a children's republic of science.

Why a children's republic of science? The emphasis on childhood was a necessity because of these authors' focus on the future. Goodrich and Abbott were less concerned with the republic-of-the-moment than they were with the republic-thatwas-to-be when the children developing all around them would come to instantiate

the Child (cit. n. 4); and Cornelia Meigs, A Critical History of Children's Literature (New York, 1953). For Goodrich, a slight biography that offers a basic sketch is Daniel Roselle, Samuel Griswold Goodrich, Creator of Peter Parley: A Study of His Life and Work (Albany, N.Y., 1968). Goodrich did compose a memoir: Recollections of a Lifetime, or Men and Things I Have Seen: In a Series of Familiar Letters to a Friend, Historical, Biographical, Anecdotal, and Descriptive, 2 vols. (New York, 1857). There is no biography of Abbott, although two unpublished dissertations provide substantive overviews and analyses: Gregory Nenstiel, "Jacob Abbott: Mentor to a Rising Generation" (PhD diss., Univ. of Maryland, 1979); and Philip Kendall, "The Times and Tales of Jacob Abbott" (PhD diss., Boston Univ., 1968). Abbott's son Edward Abbott provided a biography in "Sketch of the Author" in the memorial edition of The Young Christian (New York, 1882); his son Lyman Abbott has a biographical chapter on his father in his book Silhouettes of My Contemporaries (New York, 1922). Pat Pflieger's Web site, "Nineteenth-Century American Children and What They Read" (http://www .merrycoz.org/) features both Goodrich and Abbott prominently and is an invaluable source of primary documents, contextual information, and helpful bibliographical material.

${ }^{7}$ In terms of history of science, published interest in these authors has been minimal. There are a few pages in Keeney on both Goodrich and Abbott in Botanizers (cit. n. 1) and in Welch on Goodrich and natural history in Book of Nature (cit. n. 2). Bruce Harvey explores Goodrich's geographies in his American Geographics: U.S. National Narratives and the Representation of the Non-European World, 1830-1865 (Stanford, Calif., 2001). Abbott is the focus of Cheryl R. Smith, "Learning about Common Things: Conceptions and Uses of Science in the Juvenile Literature of Jacob Abbott" (master's thesis, Univ. of Oklahoma, 2000). Goodrich is touched on briefly in regard to a British work for children that fakes authorship from Goodrich, in James Secord's introduction to a reprint of Peter Parley's Wonders of the Earth, Sea, and Sky in vol. 3 of Science for Children, ed. Aileen Fyfe (Bristol, UK, 2003). 
it as adults. The most crucial issue in this regard was how these later citizens would handle the question of where legitimate authority resided. And here is the point at which the significance of a children's republic of science enters in: for science was a new claimant in the bid for cultural authority, vying for a place alongside such venerable sources as religion, state power, inherited privilege, ancient traditions, and military strength. Reassessment of these extant forms of authority had been undergoing scrutiny and debate since the Revolutionary era, and the explosion of natural knowledge during the nineteenth century threw into the mix the question of what the proper place of science should be within the larger polity. Goodrich and Abbott thus placed particular value on nature and science within their children's works, because inculcating self-reliance in assessing and judging this new form of knowledge and its effects would be tasks that the coming generation would surely face.

Because those who had inherited the Revolution viewed the national experiment in which they were participating as yet open ended - rather than a playing out of events whose terms had been set by remote ancestral generations and required deference to traditional norms - cultural negotiations over the meaning of all forms of authority were inescapable. As literary theorist Philip Fisher has suggested in his book of essays, Still the New World, nineteenth-century authors such as Ralph Waldo Emerson and Mark Twain knew "that there are different truths when we know ourselves to be late in time near the completion of the world (or of our own country), ready to fit a few last details somehow onto a crowded page, and when, being near the beginning of time, we find ourselves still studying the sketch of what might someday be realized." 8 Within vernacular discourse about science and nature in this time period, Goodrich and Abbott likewise saw the nation, the nation's children, and science itself as being near the beginning of time, a sensibility at odds with American scientific leaders who looked to deeply rooted Anglo-European traditions for guidance in gaining membership in a transatlantic elite whose illustrious past was seen as having set the terms for its present achievements. While there were points of convergence between these two sensibilities, there were also differences in emphasis that could lead to differences in kind, as these children learned to become American by participating in a democracy of learners.

\section{SAMUEL GRISWOLD GOODRICH AND JACOB ABBOTT: CULTIVATORS OF THE "NATIONAL NURSERY"}

Goodrich began to publish for children in earnest in 1827, with Peter Parley's Tales of America; the character of Peter Parley-a benevolent old man who had much to tell of all he had seen, done, and heard about the world-was the purported author of the books, and he became a household name. The son of a Congregational minister, Goodrich was born into a Connecticut family of Yale graduates and Federalist officeholders, which included a United States senator; he, however, ended his schooling at twelve and began a set of apprenticeships at age fifteen. As a young man, Goodrich embarked on a course of self-study and was inspired to enter the publishing business in partnership with an older friend in 1816. The untimely death not long after of both Goodrich's partner and Goodrich's young wife initiated a time of uncertainty in his

${ }^{8}$ Philip Fisher, Still the New World: American Literature in a Culture of Creative Destruction (Cambridge, Mass., 1999), 2. 
life; after a sojourn in Britain and Europe he returned home resolved to write books for children, with moralist Hannah More as his inspiration. Goodrich is credited with having written or edited 170 titles (130 for children) and to have sold seven million copies of his books in his lifetime; an 1884 estimate put the number at eleven million. He also founded two children's periodicals, Parley's Magazine and Robert Merry's Museum, which spread his influence even further. ${ }^{9}$

Goodrich began writing on scientific topics for young people early on, with The Child's Botany and Peter Parley's Tales about the Sun, Moon, and Stars in 1830; Peter Parley's Tales about Animals in 1831; Peter Parley's Book of Curiosities, Natural and Artificial in 1832; Peter Parley's Farewell in 1844 (on natural theology); A Pictorial Natural History in 1842; and The Truth-Finder; or the Story of Inquisitive Jack in 1845 (on natural history). In 1844-45, he published Parley's Cabinet Library, consisting of twenty volumes. Scientific fare in this set included A Glance at the Physical Sciences-or the Wonders of Nature, in Earth, Air, and Sky; Wonders of Geology; and Anecdotes of the Animal Kingdom. The Cabinet Library did not neglect consideration of human nature, especially in Curiosities of Human Nature and a trilogy on Indians: Lives of Famous American Indians; History of the American Indians; and Manners, Customs, and Antiquities of the American Indians. ${ }^{10}$ That he capped his literary output in 1859 with the two-volume Illustrated Natural History of the Animal Kingdom, which contained more than 1,300 pages of text and 1,500 interspersed engravings, speaks to his sustained love of scientific topics.

The younger Abbott came fast on Goodrich's heels in the early 1830s, memorably creating a series of books following the development of a fictional creation named Rollo, a small-town rural New Englander who has been called "the first truly American child in fiction to become popular." 11 The Rollo series eventually numbered twenty-eight volumes, and characters in the Rollo books such as Lucy and Jonas received series of their own; together, the Rollo, Lucy, and Jonas volumes sold a million and a quarter copies in twenty-five years. All told, Abbott is credited with 211 books, the vast majority for the juvenile audience. ${ }^{12}$ Abbott grew up on the northeastern frontier in Hallowell, Maine, where his father was a land trustee; he and his three brothers followed a common path to Bowdoin and Andover Theological Seminary. In

\footnotetext{
${ }_{9}^{9}$ The sales numbers are cited from Roselle, Samuel Griswold Goodrich (cit. n. 6), 53. Goodrich was an orthodox Congregationalist, and his work did contain religious commentary, in these books most usually in terms of natural theology.

10 This later work, two massive tomes, was sold by subscription; its publisher indicates that it reached the sale of many thousand copies. (J. C. Derby, Fifty Years among Authors, Books, and Publishers [New York, 1884], 118.) Derby appears to be referring to the first editions brought out. After Goodrich's death, the A.J. Johnson \& Son publishing company bought the stereotype plates and issued nine subsequent editions from 1868 to 1894 as Johnson's Natural History: The Animal Kingdom Illustrated. (Welch, Book of Nature [cit. n. 2], 255n12.) Goodrich's daughter recalled that the engravings alone cost thousands of dollars. Emily Goodrich Smith, "Peter Parley'-as Known to His Daughter," part 2, Connecticut Quarterly 4 (1898): 399-407, 406.

${ }^{11}$ See Faye Riter Kensinger, Children of the Series and How They Grew: Or a Century of Heroines and Heroes, Romantic, Comic, Moral (Bowling Green, Ohio, 1987); Alice M. Jordan, From Rollo to Tom Sawyer (Boston, 1948), 73. Abbott also wrote books that featured children who were free blacks. On this, see Mary Quinlivan, "Race Relations in the Antebellum Children's Literature of Jacob Abbott," Journal of Popular Culture 16 (1982): 27-36; and Jeannette Barnes Lessels and Eric Sterling, "Overcoming Racism in Jacob Abbott's Stories of Rainbow and Lucky in Antebellum America," in Enterprising Youth: Social Values and Acculturation in Nineteenth-Century American Children's Literature, ed. Monika Elbert (New York, 2008).

${ }^{12}$ Frank Luther Mott, Golden Multitudes: The Story of Best Sellers in the United States (New York, 1947), 98 .
} 
1824, Abbott signed on to a position as lecturer and then a year later as professor of mathematics and natural philosophy at the newly founded Amherst College; when innovations that he had initiated for curricular reform foundered, he left after four years to run the Mount Vernon School, an academy for girls in Boston. Abbott first came to literary fame with his book The Young Christian in 1832, which was a bestseller at home and abroad, with a quarter million copies sold. ${ }^{13}$

Abbott introduced ideas about science in his earliest work, The Little Philosopher (a set of five short books that appeared in 1829 and then combined into a single volume in 1833), which consisted of queries, prompts, and examples of simple experiments meant to get children thinking about the nature of the common objects that surrounded them in their daily lives. Science-themed volumes within the Rollo series include Rollo's Experiments and Rollo's Museum (both from 1839), and in 1842 Abbott focused on science further in the four volumes of Rollo's Philosophy (on water, air, fire, and sky). Abbott also featured technology in his Marco Paul books, which took as topics visits by a young American to such places as the Erie Canal and the Springfield Armory in 1843 and 1844, respectively. Outside of series works, Abbott can be found addressing similar topics in other formats: the steam press in The Harper Establishment, or How the Story Books are Made in 1855; technical ingenuity in a Harper's storybook, The Engineer, or How to Travel in the Woods in 1856; and natural history in the nonfictional Aboriginal America in 1860 (the first volume of a chronological set on American history). A series for older children appeared near the end of Abbott's life, in 1871 and 1872, titled Science for the Young: or The Fundamental Principles of Modern Philosophy Explained and Illustrated in Conversations and Experiments, and in Narratives of Travel and Adventure by Young Persons in the Pursuit of Knowledge.

Both Goodrich and Abbott believed they could exert the greatest possible influence on the destiny of the republic by attending to the formation of the minds and souls of the rising generation. Abbott, for example, argued that because children worked so hard to build up a picture of the world from the resources they had at hand, childish perceptions did not simply fade away: "the nature and character of the images which the period of infancy and childhood impresses upon the mind" possess a vast "influence on the ideas and conceptions, as well as on the principles of action in mature years." Goodrich thought likewise. After a decade's worth of work, he would state that although the writing of children's literature "is regarded as a humble, and often a mean, vocation, yet it is not without the means of vindication, even in the light of philosophy," for while "hardened manhood" can defy the efforts of a genius to influence its course, young people can yield "to the slightest touch, [and] may be moulded, in hundreds and thousands" by an ordinary intellect such as his "into the image of God." Along these same lines, speaking to a group of his admirers in a speech sponsored by the People's Lyceum in New Orleans in 1846, Goodrich put the matter even more assertively, asking his audience: "What field so wide, so promising, in every point of

${ }^{13}$ Abbott's religious views fell well within Congregationalist orthodoxy, although his lack of support for such older theological views as infant depravity marked him as being of a more liberal bent than other orthodox clergy in this transitional time period. In fact, his downplaying of doctrinal differences and eschewal "of Biblical literalism and anthropocentrism" held him up to complaints of heresy, as when John Henry Newman, in the Oxford Tracts for the Times (no. 73), attacked the 1834 follow-up to The Young Christian-The Cornerstone-for Socinianism. Kendall, "Times and Tales of Jacob Abbott" (cit. n. 6), 173ff. 
view so inviting, so worthy the attention of the patriot and statesman, as the national nursery, budding by millions into life and immortality?"14

Goodrich's and Abbott's works on nature and science for the young, therefore, were part and parcel of a larger mission. This fact influenced how they packaged and presented natural knowledge — not necessarily conforming to experts' views on how to structure a course in science, or on how to properly categorize scientific knowledge, but instead following their own lights on how to approach these subjects. It also influenced how their readers encountered science-as one facet of the Goodrich or Abbott brand-name enterprises that emphasized a community of learners taking an omnivorous approach to the world around them, accompanied by their own special guide, who was a companion rather than a tutor. They saw their works as being as adaptable to the schoolroom as to fireside education at home, and, in essence, they sought to build a foundation that could support the creation of a nation of lifelong learners who would be open to taking in all they could, confident in their skills of absorbing and assessing new information. ${ }^{15}$ The goal was not to create scientists per se but to provide the means to recognize one's scientific citizenship and to access the rights and privileges attendant upon this status.

In adapting their work for young minds, Abbott and Goodrich employed similar techniques, including writing in an easy conversational tone and using vivid examples and striking imagery. ${ }^{16}$ For example, in one story, rather than simply stating that the children in the chapter were walking over a deep snow, Abbott writes that "in one place, where the snow was very deep on the side of a hill, they went right over the top of a stone wall." Likewise, Goodrich presents our clinging to the earth in this manner: "The world, you know, is round, like a ball, or like the moon, and people go over its surface, and pass round it, just as flies creep round an apple or a pumpkin." In general, Goodrich had a loose, somewhat miscellaneous style, with the odd and the unusual likely to turn up at any moment (although his scientific texts were more sober in tone). Abbott's style was much quieter, and he depicted smallerscale settings than did Goodrich. John Crandall, one of the few scholars to focus on both Goodrich and Abbott in any extensive way, aptly compared the two: "The Goodrich grab bag was chock-full of a great variety of the curious and the unusual; Abbott's neat information kit was packed with careful specifications and blueprints which described the way things worked-the common and ordinary as well as the more spectacular ... Both were instrumental in widening the time and space world of

14 Jacob Abbott, Gentle Measures in the Management and Training of the Young (New York, 1871), 297. Samuel Goodrich, Peter Parley's Farewell (1839; Philadelphia, 1841), ii. Goodrich, Recollections of a Lifetime (cit. n. 6), 2:331 (emphasis in original).

${ }^{15}$ On education in this period, see: Lawrence A. Cremin, American Education: The National Experience, 1783-1876 (New York, 1980); Carl Kaestle, Pillars of the Republic: Common Schools and American Society, 1780-1860 (New York, 1983); Barbara Beatty, Preschool Education in America: The Culture of Young Children from the Colonial Era to the Present (New Haven, Conn., 1995); Clarence Karier, The Individual, Society, and Education: A History of American Educational Ideas, 2nd ed. (Urbana, Ill., 1986); and Joseph F. Kett, The Pursuit of Knowledge under Difficulties: From SelfImprovement to Adult Education in America, 1750-1990 (Stanford, Calif., 1994). Within the history of science discipline, greater attention to the history of science education is under way; as an introduction, see Kathryn M. Olesko, "Science Pedagogy as a Category of Historical Analysis: Past, Present, \& Future," Science \& Education 15 (2006): 863-80; and David Kaiser, ed., Pedagogy and the Practice of Science: Historical and Contemporary Perspectives (Cambridge, Mass., 2005).

16 Jacob Abbott, Rollo's Philosophy: Air (Boston, 1842), 10-11. Samuel Goodrich, The Tales of Peter Parley about America, 3rd ed. (1827; Boston, 1830), 61. 
the readers of this period." 17 Such a view, however, runs counter to that expressed by many commentators for whom children's literature is a fallow field unless it features Alice and her forerunners. A contemporary British author such as Charles Kingsley might mock Goodrich as "Cousin Cramchild" of Boston, U.S., in his children's fantasy The Water-Babies, and be pleased at calling forth a transatlantic Gradgrind as the dry-as-dust foil to his own cleverness; but there was more than a touch of chauvinism in this critique. ${ }^{18}$ Later commentators from the British perspective have been similarly dismissive, as in Mary Jackson's evaluation of Goodrich's books as "mediocre and preachy ... [and] sternly moralistic"- the antithesis of the "imaginative, lighthearted, humorous, and adventurous books" that had "gone underground" during the early nineteenth century when "the war in Lilliput" had temporarily been won by the forces of dullness who were fed by "an airless, inhumanly narrow view of the child's mind, capacities and needs." 19 Goodrich's and Abbott's books deserve to be read from within a more carefully considered historical context than such sweeping judgments suggest. Their work might indeed be modest, but it is, in fact, by means of the very modest compass of Goodrich's and Abbott's framework that the outlines of a convergence between American identity and scientific experience occurs: the promotion of a "plain style" scientific Americanism.

\section{“PLAIN STYLE” SCIENTIFIC AMERICANISM: RAMIFICATIONS}

In thinking about what values these science-themed works conveyed to their readers in this period of emergent debates on America's national identity, what is not to be found between the books' covers in terms of form and content plays as important a role as that which is there affirmatively. Declarations of American partisanship, for example, can be discerned, as when an author such as Goodrich urges his child readers to move beyond the books themselves and to collect native plants. Supplying instructions, he asks them to enlist the help of their parents in making a herbarium of dried specimens. In doing so, the children will be on their way to becoming botanists - and, as he confides, "I wish to have all the children who read this book become botanists." Not the least of the reasons for this, he states, is that "much more is known about plants in Europe than in America, because it is an older country. Therefore I wish to have the children here begin to learn about it, for the Americans ought not to be excelled by Europeans, since we have many more plants than they have." 20 But such sentiments rarely interrupt the flow of the business at hand, which is typically a straightforward set of descriptions of various topics on scientific themes or evocations of how one goes about seeking knowledge of the natural world.

Goodrich's and Abbott's books carried nationalistic overtones not just in content but in form and style as well. It is true that the authors did not strive after AngloEuropean refinement and that their works in general were rough-hewn and lacked literary pretension: they were designed to fit current needs, the taking on of the fireside

${ }^{17}$ John Curtis Crandall, "Images and Ideals for Young Americans: A Study of American Juvenile Literature, 1825-1860” (PhD diss., Univ. of Rochester, 1957), 381.

${ }^{18}$ Charles Kingsley, The Water-Babies: A Fairy-Tale for a Land-Baby (1863; New York, 1891), 54, $67,142$.

${ }^{19}$ Mary V. Jackson, Engines of Instruction, Mischief, and Magic: Children's Literature in England from Its Beginnings to 1839 (Lincoln, Neb., 1989), 189, 190.

${ }^{20}$ Samuel Goodrich, The Child's Botany (Boston, 1831), 17, 27. 
schooling of a wide range of common people. As such, the authors drew on an American discursive tradition of plain talking that had characterized the Puritan preachers, who designed their sermons to be understood by "the common auditory." Such a style could not afford rhetorical embellishments that foregrounded an author's studied brilliance in a virtuosic turn; instead it needed to be clothed in "homely dress and a coarse habit because it came "out of the wilderness." "The plain style evolved over time, as Perry Miller characterized it, "through the prose of Benjamin Franklin, through the cultivated rusticities of the epistles of several Revolutionary 'farmers,' into the very language of the Declaration of Independence." Literary theorist Cristanne Miller notes that "by the mid-nineteenth century Puritan 'plain style' had become the language of self-expression, the trusted idiom in America, although - or perhaps because - it had lost its bolstering doctrinal and political contexts." 21 Timeliness and breadth of reach were of the essence to get through to the common auditory in the antebellum years; the goal was not to save souls but to save the nation through the creation of republicans.

Goodrich's and Abbott's adoptions of a plain style, then, can be understood as not merely an expedient choice, or the making of a virtue out of lack of skill, but rather as affirmative stances that sought to establish a partnership in learning with their farflung audience of small scholars. In Goodrich's case, this bond was struck through the character of Peter Parley. A picture of Parley appeared opposite the first page, which opened with: "Here I am! My name is Peter Parley! I am an old man. I am very gray and lame. But I love to tell stories to children, and very often they come to my house, and they get around me, and I tell them stories of what I have seen and what I have heard." 22 Indeed, the numerous pictures of Parley that appeared invariably had a smiling group of children clustered around the old man, who seemed as an image to be an amalgam of a favorite elderly relative with all the time in the world to spare for young boys and girls, a Santa Claus who came bearing stories as gifts, and a historical figure, such as one who, when a child himself, might have sat on the knees of his Revolutionary forefathers. Parley often addressed his readers in first-person from the pages of his books. For example, at the end of Tales about the Sun, Moon, and Stars, Parley speaks to his audience directly, stating, "It would give me great pleasure to know that my little readers have been all of them pleased with these stories. To an old man that is now grey and lame, it would be a matter of delight, as he hobbles about the streets, to see in the bright faces of the little boys and girls, a smiling 'Thank you, Mr. Parley; thank you for your Stories!'" 23 Goodrich's works were written to be understood by the common auditory at its most foundational level, collapsing the distance between elite science and everyday experience.

Abbott's companion-like bond with his readers would come not from creating a fictional persona as the author but from creating child characters such as the young Rollo Holiday, whose actions and thoughts Abbott sketched with such a sympathetic pen that reviewers often remarked that he captured the way in which real children

${ }^{21}$ Perry Miller, “An American Language,” in his Nature's Nation (Cambridge, Mass., 1967), 233. Cristanne Miller, Emily Dickinson: A Poet's Grammar (Cambridge, Mass., 1987), 143-44. For another use of this concept, see Brandon Brame Fortune, "Charles Willson Peale's Portrait Gallery: Persuasion and Plain Style," Word and Image 6 (1990): 308-24.

22 Goodrich, Tales of Peter Parley about America (cit. n. 16), 9.

${ }^{23}$ Samuel Goodrich, Peter Parley's Tales about the Sun, Moon, and Stars (1830; Philadelphia, 1850), 115. 
thought and acted. Abbott devised scenarios that brought to life scenes of everyday childhood with a kind of casual fidelity that allowed his readers to recognize reflections of their own experiences within the pages of his books, providing his audience with the sense that he was writing for them, not at them. This perspective was enhanced by the fact that Rollo was the star of a series of books, which followed his growth in a sequence, just as each member of Rollo's audience had done, and continued to do, themselves.

In British didactic fare of the previous generations, it is true that authors sought to produce texts that would appeal to children as children, and in this, Goodrich and Abbott were part of a broader movement. These earlier books especially favored the dialogue format, sometimes in a more formal question and answer mode, and sometimes in terms of the presentation of fictional conversations meant to simulate ordinary discourse. Aileen Fyfe, in an essay on "Young Readers and the Sciences" in the period from 1780-1820, takes note of a relevant example in Sarah Trimmer's An Easy Introduction to the Knowledge of Nature and the Holy Scripture (1780; 8th ed., London, 1793), which "appears to consist of conversations, but there is no real dialogue." In the passage she cites, two children are taking a walk with their mother, who directs their attention in the following manner: "Do you not smell something very sweet? Look about in the hedge, Henry, and try if you can discover what it is. See, Charlotte, what a fine parcel of woodbines he has got; they are quite delightful: but notice the woodbine is very different from the oak." As Fyfe observes, "[S]uperficially this conversation uses a child's curiosity to proceed to a lesson on botanical identification, but neither Henry nor Charlotte has a voice, and their mother dictates what they should investigate." 24 It is not that adults are never sources of information in Goodrich's and Abbott's works, for they are, with knowledge sometimes verging on the encyclopedic. But there are differences, both subtle and more overt, between their work and that of other authors that temper the status quo ante of the legacy of the didactic literature they were recasting.

For example, Abbott often shows us how Rollo thinks (rather than simply describing for us what Rollo should be learning, ventriloquizing his authorial voice through parental stand-ins), and it is Rollo's curiosity that often drives the narrative (with adults responding to him, rather than the other way around). Most striking of all are the lacunae and inconclusive tangents that appear in the course of Rollo's adventures, with proper pedagogical closure sometimes taking a back seat to the contingencies of the mundane world, with all its competing dynamics. This less confined approach is exemplified in an early passage in Rollo's Museum, in which Abbott seeks to capture how the curiosity and imagination of a child let loose on his own on a summer day would work. Having set Rollo on a perch above a running brook, Abbott releases the boy's running stream of thought in like manner:

Rollo lay down upon the bridge, and looked into the water. There were some skippers and some whirlabouts upon the water. The skippers were long-legged insects, shaped somewhat like a cricket; and they stood tiptoe upon the surface of the water. Rollo wondered how they could keep up. Their feet did not sink into the water at all, and every now and then they would give a sort of leap, and away they would shoot over the surface, as if it had been ice. Rollo reached his hand down and tried to catch one, to examine his feet; but he could not succeed. They were too nimble for him. He thought that, if he could only

${ }^{24}$ Fyfe, "Young Readers and the Sciences" (cit. n. 5), 287-88, 288. 
catch one, and have an opportunity to examine his feet, he could see how it was that he could stand so upon the water. Rollo was considering whether it was possible or not, that Jonas might make something, like the skippers' feet for him, to put upon his feet, so that he might walk on the water, when suddenly he heard a bubbling sound in the brook, near the shore. He looked there, and saw some bubbles of air coming up out of the bottom, and rising to the top of the water. He thought this was very singular. It was not strange that the air should come up through the water to the top, for air is much lighter than water; the wonder was, how the air could ever get down there. ${ }^{25}$

Nor is this all. Rollo begins to question where the water in the brook comes from and is surprised "that he had never wondered at it before ... Where can all the water come from?" He then observes more bubbles coming up and thinks that finding a stick to poke about in the mud would be useful, for perhaps there is some kind of animal blowing the bubbles. Rollo's reflections are broken when Jonas, the young man who is his father's hired helper, comes by. Together the two try to reason through the mystery of the bubbles in the water, but this only leads to more questions. Jonas relates that he does not know "how the bubbles of air get down into the mud, at the bottom of the brook," but he tells Rollo he can think of another extraordinary phenomenon: the rain, which "is water coming down out of the air . . the air gets down into the water, and you wonder how it can, when it is so much lighter than water. So water gets up into the air, and I wonder how it can, when it is so much heavier." It is a question that does not get resolved. ${ }^{26}$ Whereas in the British books it is generally the case that for every question there is an answer, in Abbott's pages, it is instead the case that questions multiply and answers may or may not be forthcoming. The open-endedness of this inquiry not only reflects a characteristic of a child's curiosity rendered in naturalistic tones but also carries a message about democratic versus hierarchical polities.

The extent to which this American style could be seen as deviant is marked out by a British commentator in a lengthy essay in 1842 in the Quarterly Review. ${ }^{27} \mathrm{Au}-$ thors such as Goodrich and Abbott, the commentator claimed, had fallen "into the mistake of addressing [children] in print as they suppose them to talk to one another in every-day life" - this was "an empty simplicity" that encouraged "the love of tooeasy reading in a child, like the taste for low company in an adult." 28 The writer found the concept of presenting scientific knowledge in such easygoing terms to be a categorical mistake-education being "a thing of seriousness and solemnity," and science an especially difficult subject area. As the author remarks, "[T] he difficulty of clothing the highest subjects in the meanest language is fortunately what most effectually unmasks the futility of this 'high life below stairs' kind of proceeding." ${ }^{29}$ The class distinctions of referring to the American productions as "high life below stairs" was echoed in other descriptions that referred to the American products as "Transatlantic abominations" and "vulgar." Goodrich is scored for adapting material from his

25 Jacob Abbott, Rollo's Museum, rev. ed. (1855; New York, 1867), 15-16 (emphasis in original).

26 Ibid., 17, 18, 28, 29.

27 The Wellesley Index to Victorian Periodicals indicates that the author was Elizabeth Eastlake, a journalist and commentator on art; for biographical information, see the entry in the Oxford Dictionary of National Biography.

28 Anonymous, “Article II,” Quarterly Review 71 (1842): 54-83, 59.

${ }^{29}$ Ibid., 57, 64. 
[British] betters in the following manner: "Mr. Goodrich reminds us of those tasteless and irreverent workmen who, in the building of modern Rome, pounded the most beautiful antique marbles to make mortar!" At heart, as the author attests up front, "to combine instruction designedly with amusement is, we firmly believe, like uniting authority with familiarity, a sophistry which ends by equally destroying both." 30

This fear of the ramifications of placing the authoritative in a dangerous proximity to the familiar does not appear in American evaluations of Goodrich's or Abbott's work. A review in the Christian Examiner in 1831 states that:

Peter Parley is, we believe, a great favorite with children, because in a simple way, which they like and understand, he has been telling them tales about almost every thing. This is an intimacy, which we have no intention or wish of disturbing. The Tales about the Sun, Moon, and Stars, will furnish young people with about as much astronomy as they can comfortably bear, in such a manner as to engage their pleased attention, and imprint the facts permanently on their memory. They very early desire to know something about those splendid lights and sparkles, the sun, moon, and stars; and they may be made to know much, if their capacities are consulted as they are by their friend Parley. ${ }^{31}$

An 1836 comment on Parley's Cyclopaedia in the New Yorker states that "to the general excellence of the 'Parley' works we have already borne testimony, while their peculiar adaptation to the wants and tastes of children is a matter of perfect notoriety." The Maine Monthly Magazine likewise lauds The Animal Kingdom with the following comments: "We have here another effort of Peter Parley to please and instruct the youthful mind. The old gentleman is really indefatigable in his exertions to benefit the rising generation. He has done more in the space of a few years to raise the standard of juvenile literature, than had been accomplished in a half a century previous." Speaking on the issue of tone in Abbott's work in 1839, one reviewer stated with approbation that "we should recommend every one who wishes to learn how to address the young, how to talk to them and how to instruct as well as to entertain them, to take a seat . . . in Mr. Abbott's study." At midcentury the Methodist Quarterly argued that, in large part, Abbott's success was due to the fact that "simplicity rather than force distinguishes his style ... while a pleasing naturalness gives a lasting charm to the whole." The writer further judged that "probably no other writer in this country has so many readers, or is doing so much to form the taste and character, as well as to inform the intellect, of the rising generation." 32

\section{“A MUTUAL AND UNITED EFFORT”: ABBOTT AND HIS “LITTLE PHILOSOPHERS"}

Abbott's own presence in many of his works is that of a dramatist limning scenes that enact the process of knowledge acquisition as occurring within a community of learners in which there is no one individual who knows everything, and understanding how to handle disputes over knowledge claims or presumed authority is part of

${ }^{30}$ Ibid., 70, 79, 76 (emphasis in original), 57-58.

31 "Children's Books," Christian Examiner 10 (May 1831): 215.

${ }^{32}$ Review of Parley's Cyclopedia, New Yorker, 22 Oct. 1836, 77; review of Parley's Cyclopedia: The Animal Kingdom, Maine Monthly Magazine, July 1836, 48; “Jonas's Stories and Rollo's Experiments," Christian Register and Boston Observer, 9 Nov. 1839, 178; "Jacob Abbott's Young Christian Series," Methodist Quarterly, October 1852, 609. 
the educational task. This is one instance in which the study of nature is depicted as a natural training ground for future members of a democratic polity.

Even in the simplified form in which natural knowledge is presented in Abbott's books, the learning of facts is no simple matter of having them transferred from an authoritative source to the child mind. As Gillian Avery has noted, Abbott's aim was to produce "capable, self-reliant children who questioned, discovered, and thought for themselves," and a stable American character required the ability to experience facts firsthand in order to acquire the ability to judge authoritatively for oneself. ${ }^{33}$ This is what Marco Paul learns in his visit to the Erie Canal, for although knowledge from books has value, "when we learn by observation, we go out and see for ourselves, instead of taking the statements or explanations of others." ${ }^{4}$ Another example is drawn from Lucy and her friend Marielle's method of tide telling when at the seashore. Although they had an almanac that stated when high tide would come, "they did not like to trust the almanac entirely, especially as it was so easy to make a mark, and see for themselves." Their method of marking the water entailed placing a broken shell "at the highest place where the water came to as it rolled up the slope of sand," and then, after some time had passed, "observe whether the waves came up higher than their mark, or not so high; and thus they satisfied themselves whether the tide was rising or falling." 35

Even when it is a matter of Rollo's parents' or others' being able to provide the necessary information, the story often indicates that it is preferable for the children to try to work things through on their own. In an instance of this point of view in Rollo's Experiments, Rollo and his cousin Lucy have decided to construct a sundial, and Abbott has Rollo inquire of "his mother if she would not be kind enough to help them fix their apparatus; but she said she would give them particular directions, though she should prefer letting them do the whole themselves, and then, if they met with any difficulties, they might come and report them to her, and she would tell them how to surmount them." 36 Indeed, much of the investigation into nature in the books is selfgenerated on the part of the children, and nature is not always a willing or transparent participant: Rollo catches a fish in a dipper to study it-only to lose it; a plan to trap bees under a flowerpot in an effort to create a working beehive goes amusingly awry; Rollo's belief that an umbrella will prove to be a suitable parachute for a jump off the shed proves incorrect. The natural world is shown as open to individual inquiry but only partially knowable or malleable.

Clearly, adults are authority figures in Abbott's fiction, but they are not necessarily therefore all knowing. For example, when the family is observing the properties of magnets in Rollo's Experiments, Rollo asks his father, upon being told that the magnet's attractive powers are contained at the ends of the bar, "Well, father, what is the reason?" Mr. Holiday answers that he does not know, and the following exchange

\footnotetext{
33 This evaluation, with which I agree, is one that is at odds with some literature that discusses Abbott's advice regarding obedience to parental authority. Among relevant literature is Jani L. Berry, "Discipline and (Dis)order: Paternal Socialization in Jacob Abbott's Rollo Books," Children's Literature Association Ouarterly 18 (1993): 100-105; and Mark I. West, "Guilt and Shame in Early American Children's Literature: A Comparison of John S. C. Abbott's The Child at Home and Jacob Abbott's Rollo Books," University of Hartford Studies in Literature 18 (1986): 1-7.

${ }_{34}$ Jacob Abbott, Marco Paul's Voyages \& Travels: Erie Canal (New York, 1852), 16.

35 Jacob Abbott, Cousin Lucy on the Sea-Shore, rev. ed. (1842; New York, 1863), 103, 104.

36 Jacob Abbott, Rollo's Experiments, rev. ed. (1855; New York, 1867), 20.
} 
occurs: "Don't you know, father?" said Rollo. "I thought you were going to tell us all about it." "No," said his father. "I only know a very little about it myself. I am going to explain to you some of the facts, - such as I happen to know." 37 In the Fire volume of Rollo's Philosophy, when the family is exploring what happens when iron filings are tossed into an oil lamp, Rollo begins to speculate about what might happen with something thicker, such as a tip broken off a knitting needle. Rollo's mother takes up his train of thought and asks if there were some way "of suspending a piece of iron as large as the end of a knitting-needle in the lamp; do you think it would take the fire?" Mr. Holiday again indicates ignorance: "I don't think it would be heated hot enough. For some reason or other, I don't understand exactly what, a large piece of iron cannot be heated very hot in a small fire, even if the fire entirely covers it." ${ }^{38} \mathrm{~A}$ bit later there is more: 'Does inflammable mean,' continued Rollo's mother, 'that a thing takes fire easily, or that it burns with a great flame when it does take the fire?' 'I don't know,' said Mr. Holiday. 'I never thought of that distinction." "39

And so it goes. A great deal of knowledge is imparted in the books, but the emphasis is on the search for that knowledge, and a necessary corollary to this search is that a sincere exploration will bring the community of inquiry to points at which the answers are unclear, and this is as it should be if the dice are not loaded beforehand by pretensions of omniscience.

Abbott made this point clear at the very beginning of his authorship, in The Little Philosopher. "A wish has been frequently expressed," he explained in the new prefatory notes he added to the 1833 edition, "that more of the questions had been answered in the book, as many teachers find that they are unable to answer all themselves." Abbott explains that there were, in fact, "two very good reasons" why he had not done so: first, because there were some questions that "he did not know how to answer himself"; and second, "because he did not wish the teachers to be able to at once to answer all." Why shouldn't teachers be supplied with the means to display such omniscience? Abbott declares such a demonstration to be indefensible, whether for himself as book author or for any adult authority (and note that his explanation below specifically references paternal authority as well):

The old idea of a teacher's trying to keep up before his pupils the character of infallibility, is now exploded. All good teachers, all wise parents, are willing freely to acknowledge their ignorance, and to engage with their pupils on the understanding, that they are themselves learners, too, though in a somewhat more advanced stage. When a child brings to its parent or teacher any difficult or perplexing question, "I don't know, but I will help you find out," is the best answer . . They then, teacher and pupil, occupy common ground,-- there is sympathy between them,- - the child is encouraged by observing that his father is a learner, as well as himself.

That a parent or teacher should not be immediately all-seeing brings the question of intellectual authority into a communal rather than a hierarchical relationship between those designated as teachers and those designated as students, for all belonged to the larger category of learners. Abbott indicated that "a great many [of the questions] are

37 Ibid., 140.

38 Jacob Abbott, Rollo's Philosophy: Fire (1855; New York, 1868), 41.

39 Ibid., 47. 
intended to awaken the common curiosity and interest both of parent and child, and to engage them in that most useful and delightful employment, a united and mutual effort, in search of knowledge." 40

In Abbott's knowledge community, both men and women can be authoritative sources, and girls and boys alike take on the roles of inquirers. This is true when adults are present, as when Rollo encounters his former grade-school teacher, and she becomes involved in his investigations (into optical illusions such as the rainbow, or in regard to water pressure in the digging of a small canal from the brook), or when his mother proposes some experiments with feathers and air temperature on a rainy day when he and his brother are out of sorts. It is also true in moments of recreation among the children themselves. In one episode in which Abbott describes Rollo at play with Lucy and his little brother, Nathan, when out-of-doors, here is Rollo's suggestion for how they will amuse themselves: "O Lucy we will play go up the mountains. There is a hill for us. That shall be Chimborazo.' . . . They played that Rollo was the guide, and that Lucy was the philosopher. Nathan was the philosopher's servant."41 In Rollo's Museum, it is Lucy who is elected by the children to be in charge of their search for curiosities for their natural history cabinet, and they are to follow her decisions as to any questions that arise among them. ${ }^{42}$

The appearance of female characters was no accident. Certainly, the idea that mothers had a special role to play in educating children's moral development and guiding their early years within the domestic sphere was an increasingly prominent theme in this era. The vogue for the pedagogical theories of Rousseau, Pestalozzi, and Fellenberg, in which children were to be given greater freedom to learn at their own pace, and to involve all their senses via object teaching, also was highly adaptable to the home setting. But there is more to this gender emphasis than simply an interest in maternal guidance for small children, for in the antebellum period the idea that the female intellect was the equal of males gained increasing force, with a complementary surge in opportunities for girls to receive the same advanced educational training as boys (of which Abbott himself was a part, in his years running the Mount Vernon School). Recent histories of women's education in this period have found that although "excluded from most colleges in institutions called seminaries, academies, and high schools, women received education very much like the education men received in the colleges, academies, and high schools they attended." Ideologies that professed no gender distinctions in mental power became widespread in the antebellum era, because "the realm of the intellect was regarded as being separate from other arenas of life" - that is, one need not believe in equality for women in the legal, political, or domestic sphere to affirm that girls and women not only could engage in mental self-improvement but that they should, and thus "few gender distinctions were made in regard to academic studies." This includes science instruction. Kim Tolley has shown that instruction on science in academies for girls was as likely as for boys, and in fact girls could end up having more exposure to science, because of the greater emphasis on instruction in Greek and Latin for boys-success at which

40 Jacob Abbott, The Little Philosopher, for Schools and Families: Designed to Teach Children to Think and to Reason about Common Things; and to Illustrate for Parents and Teachers Methods of Instructing and Interesting Children (Boston, 1833), 12 (emphasis in original).

${ }^{41}$ Abbott, Rollo's Philosophy: Air (cit. n. 16), 12-13.

42 Abbott, Rollo's Museum (cit. n. 25), 80-83. 
was needed for entry into college. Outside of formal schooling, Deborah Jean Warner noted some time ago that "in the antebellum years, before it had become a recondite professional specialty, science played an important and wide-ranging role in American culture. As members of that culture women were encouraged to learn about science and to involve themselves in its pursuit." 43 Although the relatively equitable role that the female presence played within Abbott's depictions of engagement with science may surprise us today, it should not.

In addition to the relatively free equality that existed between the sexes in this regard, Abbott also makes clear that the ability to impart knowledge could come from sources other than parents or classroom teachers. Jonas, for example, is often portrayed as being able to teach Rollo about the natural world, despite the fact that he is a hired worker, aged perhaps thirteen or so, who has received little in the way of schooling. When he offers one day to give Rollo and his cousin James a lecture on the displacement of water, Rollo laughs and challenges him, arguing that Jonas could not give lectures because he is not a teacher. But Jonas insists that he is, and "at any rate if you will get James to come and help you make an audience, you may see if I can't lecture." And so he did. In another volume, he shows Rollo and his younger brother, Nathan, several experiments that can be performed with a bellows, instructing them that "I will be the professor and you two shall be my class in philosophy, and I will direct you how to make the experiments." 44 Jonas, in fact, plays a large part in the discussions about how nature works, with some of what he knows coming from books he has borrowed from Rollo's father in a kind of self home schooling, and much more from his personal experiences stemming directly from his own labor. A discussion about the nature of oxygen, for example, proceeds from work that Jonas is doing in clearing a nearby field by piling the debris into heaps that will be set on fire. Jonas asks Rollo what he supposes it might be that makes anything burn, and Rollo answers that it burns "itself." Jonas answers no, explaining that "the air makes it burn: it must have good air around it, or else it won't burn. There is something in the air which I call the life of it; this makes the fire burn. But when this is all gone, then that air will not make fire burn any longer." He then explains that the fire that Rollo is building inside a stump will need to have an opening from underneath the debris he has set inside if it is to burn successfully. Rollo then asks what it is in the air that causes the fire to burn, and Jonas answers that he has forgotten the name- "I knew once . . . but it was a hard word, and I have forgotten it" - but that "it is some part of the air, which goes into the fire, and is all consumed, and then the rest of the air is good for nothing." 45

Jonas is a key pivot for the plain style of Abbott's scientific books. He is clearly intelligent and reflective and goes about his work with a spirit of inquiry equal to his practical competence and the reliability of his judgment. Although it is the character of Rollo that is most often remembered in later generations when Abbott's work

${ }^{43}$ Margaret A. Nash, Women's Education in the United States. 1780-1840 (New York, 2005), 54, $1,1$. For further elaboration of women's pursuit of intellectual equality and the support for it, see Mary Kelley, Learning to Stand and Speak: Women, Education, and Public Life in America's Republic (Chapel Hill, N.C., 2006); Kim Tolley, The Science Education of American Girls: A Historical Perspective (New York, 2003); and Deborah Jean Warner, "Science Education for Women in Antebellum America," Isis 69 (1978): 58-67, 67. See also Kohlstedt, "Parlors, Primers, and Public Schooling” (cit. n. 1).

44 Jacob Abbott, Rollo's Philosophy: Water, rev. ed. (1842; New York, 1855), 109-10; the lecture occurs later in chapter 11. Abbott, Rollo's Philosophy: Air (cit. n. 16), 51.

${ }^{45}$ Abbott, Rollo's Philosophy: Air (cit. n. 16), 127-28, 140. 
is recalled, the character of Jonas made a notable impression on contemporaries as well. Looking back in 1866, one commentator fondly recalled Jonas and the other Jonas-like figures Abbott invented, summing up his characteristics thusly:

Jonas is an admirable creation - the typical New England boy; such a boy as every one of us has been or has known. Steady, sensible, sagacious ... Domestic and agricultural virtues adorn his sedate career. His little barn-chamber is always neat; his tools are always sharp; if he makes a box, it holds together; if he digs a ditch, there the water flows. $\mathrm{He}$ attends lyceum lectures, and experimentalizes on his slate at evening touching the abstruse properties of the number nine. Jonas is American Democracy in its teens; it is Jonas who has conducted our town-meetings, built our commonwealth, and fought our wars. ${ }^{46}$

Nothing could be further from the case of Jonas's role in the British books to which Abbott's Rollo series might be compared most profitably: that of Maria Edgeworth's Harry and Lucy stories, which also show the acquisition of scientific knowledge within a domestic setting. Members of an at least upper-middle-class family, Harry and Lucy are being tutored at home by their parents-in the end, Harry hopes to become a great scientist, and Lucy is learning to train her mind so as to be a good intellectual companion to one such as Harry. There is no comparable figure in these British stories to Jonas, in which a working-class individual carries a large responsibility for embodying the values of securing knowledge about the natural world to the young who look up to him as a guide despite his lack of scientific credentials.

Unlike Harry and Lucy, whose lives are filled with instruments such as barometers, hygrometers, and portable camera obscuras, Rollo and his family and playmates are not supplied with handy scientific instrumentation by Abbott in order to provide regular classroom-type lessons in the guise of ordinary domestic life. Neither are wellendowed deus ex machina figures employed to provide sophisticated instruments, as Edgeworth does for her young scholars, as when an uncle who was formerly a physician moves into the neighborhood, bringing with him "a microscope, an electrifying machine, an airpump, and a collection of fossils" and, as the children discover when they visit him, an industrial-strength barometer, a wooden orrery, and a pair of very large globes. ${ }^{47}$ In the sequel, the children visit Sir Rupert-representing scientific nobility at its most impressive-who has an exquisitely outfitted castle laboratory. In the American books there are no optical instruments of any kind, let alone anything more ostentatious to be had: all that is at hand is the family, broadly construed, everyday items for ordinary use, and the natural world in which the family is embedded. The tools of their impromptu "philosophy classes" are of the most familiar sort, such as a bellows from Jonas's workshop. In fact, the magnet mentioned above was not a special instrument or toy, but an ordinary worn-down steel file that Jonas had magnetized to use in the workshop for picking up nails. Science is not the "star" of these science-themed books: it is, instead, the members of the community of inquiry themselves, engaged in their united and mutual effort to learn about common things.

46 Thomas Wentworth Higginson, “Children's Books of the Year," North American Review, Jan. 1866, 236-49, 246.

${ }^{47}$ Maria Edgeworth, Harry and Lucy, with Other Stories (New York, 1836), 1:34, 37. 


\section{“KNOWLEDGE IS COMMON PROPERTY": GOODRICH ON KNOWING ONE'S PLACE}

Goodrich does not have a set of players to stride across his pages, as does Abbott, enacting the creation of scientific Americans: instead, it is Parley who constitutes the figurehead around whom this virtual community is brought into existence through the steady stream of scientifically based material he pens, in a variety of formats suitable for nonreaders, young children, older youth, and family circles. It would be possible during the middle decades of the nineteenth century for a child successively to grow out of and grow into a Parley-produced scientific text at every stop along his or her developmental path - and then turn around and introduce the same pattern for his or her offspring, such was the prolific nature and popularity of Goodrich's works. Goodrich indeed had his entrepreneurial eye focused on the economic return of exploiting a multiplicity of market niches, but these niches also are consonant with the need to supply materials suitable for the developmental trajectory of a particular kind of young American: that embodied by Abbott's Jonas.

Goodrich also held to a conviction that Americans formed a community of learners, not the least in having to teach each other how to establish a new nation that would endure. This was not a matter for a nation's leaders alone; Goodrich was a staunch republican. For example, he agrees that "it is a matter of necessity that professional men should possess extensive erudition. But there is no reason that it should be restricted to them." Indeed, Goodrich is thoroughly unimpressed with the idea that a university degree raises one above the common citizenry. He points to the illegitimate birth of the university as an institution in support of this view:

From the time that Europe began to emerge from the dark ages, it had been a matter of pride with many sovereigns to aid the revival of learning. But how was this done? Not by attempting to enlighten the whole community, but by the founding of colleges or universities, where a chosen few might be instructed in every branch of human knowledge. The idea was to establish institutions on a magnificent scale, endow them with ample funds, store them with rich libraries, collect into them every kind of philosophical apparatus, and place them under the guidance of men distinguished alike for learning and genius. Here the sons of the rich or the favorites of the powerful were to be assembled and instructed. Thus, while the people at large were to be left in darkness, a blaze of glorious light was to be collected into one focal point. ${ }^{48}$

Universities the United States might have, but it is the education of all that is of prime importance, and "the great discovery of our pilgrim fathers" was that "in opposition to the scheme of despotism, which would concentrate and confine knowledge in a university, they sought its diffusion over the people at large." To focus a society's energy on an educational elite is inefficient, undemocratic, and immoral. On the following point, Goodrich is absolutely certain: "The truth is, that knowledge is common property, and those who possess it are bound to distribute it for the benefit of others." 49 He insists that "the mechanic, the farmer and the tradesman may be benefited by knowledge, and may, without neglect of their proper vocation, cultivate a love of letters." To enlighten the community at large, Goodrich argues, one cannot escape the fact that "the plain truth is, that human improvement, like heat in water,

${ }^{48}$ Samuel Goodrich, Fireside Education (New York, 1838), 391, 17.

${ }^{49}$ Ibid., 19, 59. 
works upward and not downward. If you would warm the whole mass, begin at the bottom." ${ }^{50}$ For those Jonases to be as well educated as they deserved to be, some means toward this end needed to be effected.

Goodrich's approach is emphasized in the preface to A Pictorial Natural History: Embracing a View of the Mineral, Vegetable, and Animal Kingdoms. In it, he explains that the text could be mastered in a few months-adaptable to use in a common school, but also, he states so that "common readers" can have at hand an outline of the natural world, such that those who have neither the time nor means to currently explore further will have embedded in their minds a logical structure that would allow an individual "to retain his acquisitions, and indeed to make constant accessions to them in after life." Goodrich notes that "the largest portion of society begin and finish their technical education" in a primary seminary, and numerous readers may have themselves fallen into this category. This book, he offers, is but "a humble attempt to aid and encourage the inquirer in the outset of his search after a kind of knowledge hitherto inaccessible to many learners." 51 Why inaccessible? In his Illustrated Natural History, he explains that without works such as his, "the world at large" would be prevented from becoming "participators in the golden fruit of scientific research," for the communications of scientific men would otherwise "remain beyond the reach of the million, locked up in quartos, hidden in the libraries of the learned." 52 The general public could not depend upon aristocrats of learning to share what should be "common property." In writing about science for children and young people_-and, no doubt, adult readers of these works as well—Goodrich saw himself as doing more than simply increasing the amount of content stored in his readers' minds. He was convinced that he was setting natural knowledge at liberty and creating freer minds in doing so.

In his scientific presentations Goodrich takes special care with the opening pages of his works to establish the idea within his readers that they are already equipped to think deeply and broadly about the nature of the world they live in. The Pictorial Natural History opens with a chapter on "The Material Universe" and an exercise in limbering the mind straight off: the reader is asked to begin where he is seated and to acknowledge that what we survey "is limited to a very small part of the whole system of nature. If we look beyond the house in which we live we see other houses, and also fields, and hills, and plains." He then takes the reader in his or her mind's eye out further and further in greater circles until the reader is contemplating the immensity of the earth, then its diminished status within our solar system, and then on to the immensity of space, where "every little star which is seen twinkling in the sky, is a sun like ours, supposed to be surrounded, too, with a similar troop of planets, which like our earth, are the residences of animated creatures." He takes his youngest readers on a similar journey in Tales about the Sun, Moon, and Stars, although he cleverly uses the captivating image of a hot-air balloon to have his readers begin their journey from

50 Ibid., 391, 348.

${ }^{51}$ Samuel Goodrich, A Pictorial Natural History: Embracing a View of the Mineral, Vegetable, and Animal Kingdoms (1842; Boston, 1854), iv, iii.

52 S. G. Goodrich, Illustrated Natural History of the Animal Kingdom, Being a Systematic and Popular Description of the Habits, Structure, and Classification of Animals from the Highest to the Lowest Forms, with their Relations to Agriculture, Commerce, Manufactures, and the Arts, 2 vols. (New York, 1859), 1:vi. For a brief discussion of this work and of Goodrich, see Welch, Book of Nature (cit. n. 2), 138-39. 
home to outer space. The text starts with: "Here is a picture of a balloon! It is an immense bag of silk, as big as a small house. A net is thrown over it. To the bottom of this net a little car, like a boat, is attached." As the pictured balloon begins to ascend, he asks his readers to notice "the little flag which the man is waving in his hand," the net that can still be seen over the balloon, and the fact that one "can easily distinguish the countenances of the fearless men who are now going to take a ride into the regions of the clouds." He offers a further picture showing how small the house-size balloon now looks, showing it to be "scarcely bigger than a pin's head." 53

In the Pictorial Natural History, a large image of the earth as viewed from spacenearly half the page, with just six lines of text below it - dominates the book's first page in the opening chapter. This image is one of Goodrich's most beloved devices, used early on and recurring frequently. It appears, in fact, in the 1827 volume The Tales of Peter Parley about America, his very first children's book on any topic. In this book, he interrupts his narrative about early America midway through, in order to first "make you understand some things" about the nature of the earth and moon. The moon, Goodrich relates, "looks small, because it is very far off; but it is really a great world, with mountains, and rivers, and seas upon it." Now this is interesting information in itself, but Goodrich goes on next to point out that "if we were on the moon, the earth we live upon would look small and round, like the moon." And Goodrich supplies a picture of the world as it would be seen from outer space and remarks that, "I suppose it looks on this picture as it does to the people in the moon." For those children who went on to read Tales about the Sun, Moon, and Stars in 1830, they would learn that "for those people who inhabit the stars, our earth is itself a star. Look up at one of the stars in the sky, and imagine yourself upon it. The world, dwindled by the distance, would appear to you a little glimmering light, so faint and far, as to be scarcely visible," and a newer, more evocative engraved image appears. ${ }^{54}$ These two images from Tales about America and Tales about the Moon, Sun, and Stars will appear again in later volumes, including the Pictorial Natural History (1842), A Glance at the Physical Sciences (1844), and The Wonders of Geology (1844). It is a thrifty recycling of useful material, but I would argue that its presence across his varied editions also indicates that it represents a conceptual point of significance to Goodrich. In particular, by encouraging a perspectival shift in his readers, Goodrich assists them, in word pictures and in illustrations, to look on their familiar world with alien eyes to better understand it.

${ }^{53}$ Goodrich, A Pictorial Natural History (cit. n. 51); Goodrich, Tales about the Sun, Moon, and Stars (cit. n. 23), 9-13.

${ }^{54}$ Goodrich, Tales of Peter Parley about America (cit. n. 16), 60, 60-61, 61. Goodrich, Tales about the Sun, Moon, and Stars (cit. n. 23), 22. The more scholarly A Glance at the Physical Sciences from 1844 hedges on the question of the moon's inhabitation. The text reports that it does not appear that there are fluids on the moon's surface, and without air and water it could not be inhabited (or at least life would be different from that on our planet). A footnote, however, offers two authorities who hold that the moon "is inhabited by rational creatures" (23). On the question of planetary habitation in this era, see Michael Crowe, The Extraterrestrial Life Debate, 1750-1900: The Idea of a Plurality of Worlds from Kant to Lowell (Cambridge, UK, 1986). For an introductory commentary about visual images in popular culture, along with a discussion of a more sophisticated use of the view from another planet concept, see Bernard Lightman, "The Visual Theology of Victorian Popularizers of Science: From Reverent Eye to Chemical Retina," Isis 91 (2000): 651-80. Lightman highlights an image from Jefferys Taylor's A Glance at the Globe and at the Worlds around Us (1848), in which the earth is seen from the vantage point of the moon, and that also includes a rendering of the lunar landscape (651-52). 
It is not only in astronomical passages that such perspectival shifts occur. In his discussions of foreign peoples, Goodrich makes frequent use of brief, shorthand stereotyping to sum up their "key" characteristics, confirming conventional prejudices in the process. And yet, there are times when Goodrich interrupts the text to cast doubt on the generalizations that have been presented, a tactic that Bruce Harvey has characterized as "the Peter Parley conscience, a reluctance to endorse unqualified claims about any particular culture's alleged inferiority." 55 The result is again to introduce frameworks at odds with the expected, which-briefly-displace readers from their own cultural locations and to perceive the statements from the point of view of the subjects under discussion themselves. (Goodrich, however, never goes so far as to have these others actually speak for themselves.) This is a tactic that makes descriptions of human nature more complicated and confused than they would be otherwise in a rationally ordered universe.

For example, Goodrich argues, distorted perception is responsible for what we know of Indians. It may not be surprising that he depicts the Spanish as "conquerors and spoilers of America [who] had strong motives for first hating, and then defaming, the Aborigines." To appropriate the riches of Mexico, Cortez and his men slaughtered millions and enslaved the rest. To "justify his conduct to his own conscience and the world at large" he had therefore to represent these peoples "in the most degrading and revolting colors." But Goodrich holds the English responsible as well. It was true that the colonists were "almost constantly in a state of active hostility with the savages. . . The savages were, therefore, enemies, and how hard is it to judge fairly of those we hate!" The English also, "to make their conduct stand fair before the world," adopted the strategy of "portray[ing] the Indians in the most unfavorable light" and "the misrepresentations, proceeding from the early settlers of America ... constituted the main sources of history." 56

But self-interested motives are not the only form of distortion. Goodrich also points out that "the natural disposition to interpret the bosoms of others by our own, has led historians and philosophers to estimate the Indians by transatlantic standards of thought, feeling and action." However natural the disposition, it is likely "to lead to false conclusions." Anyone who has struggled to master a new language knows what it is like to:

become acquainted with a new, and before unknown, region of thought; how original then, and how different from our own, must be the mind, soul and character of a people, who have grown up by themselves, shaping out, in isolation of all the rest of the world, and in utter ignorance of all but themselves, their own manners, customs and institutions! In analyzing such a race we should study facts - abstain long from theory, and constantly be on our guard against bringing them up to be measured by the artificial rules established in our own minds..$^{57}$

That Goodrich cannot live up to his own standard does not make it any less interesting that he struggles with it.

This is a refrain that occurs in other contexts as well. In Peter Parley's Tales of Af-

${ }^{55}$ Harvey, American Geographics (cit. n. 7), 45. Harvey adds that in this regard Goodrich's "works do become at times self-conscious about the grounds of their own authority" (45).

56 Samuel Goodrich, Lives of Celebrated American Indians/by the Author of Peter Parley's Tales (Boston, 1843), 1, 2.

${ }^{57}$ Ibid., 3, 4, 5 . 
rica, for example, Goodrich informs his readers that "formerly, the accounts given us of the people of Africa, represented the negro races, as a stupid, debased portion of the human family, only fit to be the slaves and servants, of the rest of mankind. But modern travellers, more worthy of credit, give more favorable representations . . . the Negroes of Central Africa are more intelligent, and more civilized, than the world has been led to believe them." It is also the case that "the Caffrees and the Hottentots are now known to be superior in every respect, to what their Dutch neighbors, used to say they were." 58 This uneasiness concerning what had been taken to be fact appears even within the conservative confines of a family library, prompted by an encounter with human nature in a variant beyond the Anglo-European norm. As more facts are known, the old ones shift in relation to the new frame or are even discredited outright. What is taken to be natural is not necessarily stable knowledge, for a lack of perspective can compromise the basis for producing authoritative knowledge.

\section{CONCLUSION}

In the United States, the explosion of natural knowledge that occurred in the nineteenth century intersected with cultural patterns still very much in flux, and this fluidity possessed interesting implications for the organization of knowledge. It was by no means an assured fact that deferential patterns toward an intellectual elite would take hold, especially in a society that celebrated the "common man." It was a situation in which contemplating the nature of democracy could lead to imagining the democracy of nature, where scientific knowledge would be seen as a shared cultural possession, not simply the province of expert practitioners.

Goodrich and Abbott displayed a sense of mission embedded within the plain style imperative of their works, which was to reach as many young people as possible within the sphere of the common auditory, not simply to inculcate a rote morality or to impart facts for facts' sake, but to bring as many individuals as possible within a circle of lifelong learning and mutual improvement. They saw the burgeoning sphere of natural knowledge as belonging to everyone, and so they worked hard to put this knowledge into public circulation and into the hands of America's future citizens. In this sense, the larger community and the scientific community were coextensive, not disjunctive - as long as the circulation of knowledge flowed freely through republican channels. This was, in some ways, an innocuous educational goal: but to hold it as normative would be to place this goal at odds with the growing assertion of scientific leaders-even if mostly uttered sotto voce in these middle decades, but to become more dominant toward the century's end-that what occurred within the vernacular sphere was too superficial to count as meaningful or significant in terms of the constitution of a community of knowers.

Historians of science may still tend to evaluate past progress for a society by the numbers of real scientists produced, the pace of real research conducted, and the amount of real recognition bestowed upon professional aspirants by those of higher status, but these are not the only measuring sticks by which to assess the nature of a society's scientific character. In the mid-nineteenth century, Almira Hart Lincoln Phelps spoke for the standards applied by the plain style scientific Americans, at the end of her Familiar Lectures in Botany: "The spirit of our government is highly

${ }^{58}$ Samuel Goodrich, The Tales of Peter Parley about Africa, rev. ed. (Philadelphia, 1836), 123. 
favorable to the promotion and dissemination of knowledge; and although Europe may boast of many stars which irradiate her firmament of letters, shining with brilliant lustre amidst the surrounding darkness of ignorance, may we not justly feel a national pride in that more general diffusion of intellectual light, which is radiating from every part, and to every part of the American republic!" 59 Phelps may have been overly enthusiastic in her estimation, but she describes well the goal toward which these midcentury educationists were striving.

Further exploration of the connections between childhood nature and the issue of scientific citizenship within American nature offers a key pathway to insights about the relationships between science and national identity. As the nation was on the threshold of evolving into a changed relationship with the Old World in the postbellum period, another commentator also focused on the image of the child, this time as reflected in the children's literature of the mid-nineteenth century, positing that it still had a role to play in the coming cultural transition. "Every American child, unless he has the misfortune to be transplanted across the Atlantic for schooling, is American in early associations; while every highly educated man among us has half his thoughts in Europe," this author noted. The opportunity to read through a wide array of children's books proved to be a pleasant "reversion" to "the vernacular" for adults who were "oversaturated with Transatlantic traditions," and the author commented that "it is singular how much more of the aroma of American nationality one can get from our children's books than from any others ... External nature itself seems more sincere and genuine." Some aspects of American identity that had been nurtured in the national nursery seemed to be harder to cultivate in the later decades, and the writer imagined that "an epoch may yet come" where "a maturer civilization ... shall grow from the common ground, and be as fresh and healthful as this childish society." 60 Peter Parley and Rollo would no doubt have agreed.

${ }^{59}$ Almira Hart Lincoln Phelps, Familiar Lectures on Botany, rev. ed. (Hartford, Conn., 1836), 235 (emphasis in original).

${ }^{60}$ Higginson, "Children's Books of the Year" (cit. n. 46), 249, 248, 249. 